\title{
Actively Pursuing Knowledge In The College Classroom
}

\author{
Paul Andrew Johnson, Bowling Green State University, USA
}

\begin{abstract}
The purpose of this study was to compare course evaluation responses of students enrolled in several sections of a graduate level human growth and development course taught with a traditional lecture/textbook approach to the course evaluation responses of students enrolled subsequent sessions of the same graduate human growth and development course taught with an active learning approach. Quantitative and qualitative data indicated that students in the sections taught with an active learning approach rated those sections significantly higher than students in sections taught with a traditional lecture/textbook approach.
\end{abstract}

Keywords: active learning; effective instruction; higher education instruction

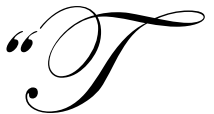

he power point lectures were deadly and the textbook was boring." Ouch! Those are not words a college instructor wants to read on a course evaluation. Until I read these words I never realized that power point bullets could be deadly but they were for my students. But if it hadn't been for such critical, albeit painful, feedback I never would have changed my "sit and get" text-based lectures to actively engaging my students in their own learning.

As I began to explore how I might more effectively teach my students, little did I realize I was entering into an on - going debate over what constitutes effective teaching at the college level. As I began my research I was immediately struck by one quote from the work of the American Association for Higher Education Task Force on Best Practices in Higher Education published in 1987:

Learning is not a spectator sport. Students do not learn much just by sitting in class listening to teachers, memorizing prepackaged assignments, and spitting out answers. They must talk about what they are learning, write about it, relate it to past experiences, and apply it to their daily lives. They must make what they learn part of themselves. (Chickering \& Gamson, 1987, p.3)

\section{LITERATURE REVIEW}

\section{Active Learning}

What Chickering and Gamson (1987) were describing is what has come to be known as active learning. Paulson and Faust (2011) in an article entitled Active Learning for the College Classroom defined active learning as:

anything that students do in a classroom other than merely passively listening to an instructor's lecture. This includes everything from listening practices which help the students to absorb what they hear, to short writing exercises in which students react to lecture material, to complex group exercises in which students apply course material to "real life" situations and/or to new problems. (p.1)

Writing in an article entitled What Makes Lectures 'Unmissable'? Insights into teaching Excellence and Active Learning, Revell and Wainwright (2009) described active learning in these terms:

Active learning refers to the idea that students are actively engaged in the learning process, rather than passively absorbing lectures. Active learning involves discussion, problem solving, presentations, group work such as buzz. 
groups, brainstorming, role plays, debates - anything that gets students interacting with each other and engaging with the lecture material. (p.209)

In Getting Active in the Large Lecture, Huerta (2007) described active learning very simply when he wrote that "The key is that students are not passive participants in their learning; rather, they are engaged and active in the learning process" (p. 238). Prince (2004) described active learning as learning that includes techniques that engage students in the learning process by engaging them in meaningful learning activities and reflection while Rotenberg (2005) stated the essence of active learning as "To make knowledge active, one must acquire it through an activity" (p.28).

Barkley, Cross, and Major (2005), citing recent research in support of active learning, wrote "The closing decades of the twentieth century were exceptionally rich in producing a better understanding of the learning process. Critical to our understanding of that process is the basic tenet of modern cognitive theory: learners must be actively engaged in learning" (p. 11).

Efforts to bring active learning to higher education began in earnest with the publication of a work that has since become known as the Seven Principles for Good Practice in Undergraduate Education. These principles, developed by the American Association for Higher Education (AAHE) Task Force on Best Practices in Higher Education and published the AAHE Bulletin in 1987, "rest on 50 years of research on the way teachers teach and students learn, how students work and play with one another, and how students and faculty talk to each other" (Chickering \& Gamson, 198, p.7). According to Rotenberg (2005) this work represents one of the few statements about university teaching that is nationally recognized (p. 26).

Two of these seven principles speak directly to the importance of actively involving students in their own learning: encouraging cooperation among students and encouraging active learning. The task force pointed to the importance of students working together with other students in a cooperative and collaborative setting when they stated that:

Learning is enhanced when it is more like a team effort than a solo race. Good learning, like good work, is collaborative and social, not competitive and isolated. Working with others often increases involvement in learning. Sharing one's ideas and responding to other's actions sharpens thinking and deepens understanding. (Rotenberg, 2005, p.27)

Paulson and Faust (2010) make clear that cooperative learning and collaborative learning are subsets of active learning strategies. According to Paulsen and Faust "cooperative learning covers the subset of active learning activities which students do as groups of three or more, rather than alone or in pairs" (p.1). On the other hand collaborative learning "refers to those classroom strategies which have the instructor and the students placed on an equal footing working together in, for example, designing assignments, choosing texts, and presenting material to the class" (p.1).

In one study of student- centered approaches to teaching, McKeachie, Pintrich, Lin, and Smith (1986) concluded that " the best answer to the question of what is the most effective method of teaching is that it depends on the goal, the student, the content, and the teachers, but the next best answer is 'Students teaching other students"' (p.63).

In fact, Meyers and Thomas (2003) contended that it can be difficult for many students to comprehend concepts if they are only receiving information from their professors and according to Barkley et al. (2005) "research support for the impact of peers on student learning is extensive and it comes from broad scaled studies of college environments as well as from studies directed more specifically to the effects of collaborative learning in the classroom" (p.14). Astin (1993), for example, conducted large-scale statistical studies across hundreds of colleges using twenty-two measures of student learning outcomes and concluded that two factors significantly contributed to academic achievement, personal development, and student satisfaction. Those two factors were interactions with fellow students and interaction with faculty members. Astin (1993) wrote that: 
Research has consistently shown that cooperative learning approaches produce outcomes that are superior to those obtained through traditional competitive approaches, and it may well be that our findings concerning the power of the peer group offer a possible explanation: Cooperative learning may be more potent that traditional methods of pedagogy because it motivates students to become more active and more involved participants in their learning process" (p. 427).

In a similar fashion, Barkley et al. (2005) unequivocally made the case for the effectiveness active learning and the research that supports it when he stated that:

The predominant conclusion from a half-century of research is that teachers cannot simply transfer knowledge to students. Students must build their own minds through a process of assimilating their own understandings. Meaningful and lasting learning occurs through personal active engagement. (p. xi)

\section{ACTIVE LEARNING AND HIGHER - ORDER THINKING}

Chickering and Gamson (1987) concluded that to learn effectively students must do more than just listen effectively: They must be actively engaged in reading, writing, discussing, and problem solving. Most importantly, according to Chickering and Gamson, to be actively involved in their own learning, students must engage higherorder thinking skills such as application, analysis, synthesis, and evaluation as they process information.

Students need to critically evaluate information and not just passively accept it. Oliver and Utermohlen (1995) see students as too often being passive receptors of information; information that is exploding exponentially in its amount. According to Oliver \& Utermohlen (1995) students need to "develop and effectively apply critical thinking skills to their academic studies, to the complex problems that they will face, and to the critical choices they will be forced to make as a result of the information explosion and other rapid technological changes" (p.1).

In similar fashion Barak, Ben-Chaim, and Zoller (2007) pointed out that "Our ever-changing and challenging world requires students, our future citizens, to go beyond the building of their knowledge capacity; they need to develop their higher-order thinking skills, such as critical system thinking, decision making, and problem solving" (p. 354) and as Raviv (2009) put it:

The 21st century is characterized as a dynamic era of incessant changes in all fields of life. The amount of knowledge in all areas of study is increasingly growing in an enormous way. New knowledge is not only accumulating continuously, but often replaces previous knowledge. Knowledge is thus becoming obsolete at an ever faster pace. No one today is able to embrace in his/her mind all the existing knowledge, even in a single content area. In light of this, the traditional approach, according to which the main role of education is to equip learners with information that they might need in the future, is no longer valid. ( $p .378$ )

Finally, Ten Dam and Volman (2004) viewed the teaching of higher order thinking skills, including critical thinking, as vital to the future of democratic nations. She wrote that "critical thinking is a crucial aspect in the competence citizens need to participate in a plural and democratic society, and that enable them to make their own contribution to that society" (p. 360). The results of more recent studies concerning the effectiveness of teaching methods support the conclusions of Chickering and Gamson and favor active learning strategies as the method to accomplish the goal of actively engaging students in higher order thinking and learning. For example, the work of De Caprariis, Barman, and Magee (2001) suggested that while lecture leads to the ability to recall facts, discussion produces higher levels comprehension. Similarly, Exley and Dennick (2004) found that while active learning methods are comparable to traditional lectures in promoting mastery of content, they are superior to lecture only methods in promoting the development of students' cognitive and communication skills. These findings, and others like them, strongly suggest that active learning strategies themselves encourage students and teachers to engage in a "deep" versus "surface" approach to learning. According to Ramsden (1991), surface learning is characterized by rote learning while, deep learning is characterized by a genuine interest in the subject, in which students are encouraged to critically examine and reflect upon content and in the process integrate it into what they already know; in other words according to Ramsden, they come to own it. 


\section{ACTIVE LEARNING VERSUS TRADITIONAL LECTURE}

With its emphasis on actively engaging students in the learning process, active learning stands in sharp contrast to the traditional lecture format where material is passively delivered to students by lecturers who pass on their wisdom to students who are engaged in taking notes for an upcoming exam. Freire (1995) referred to this approach as the 'banking' model of education, where:

Education becomes an act of depositing, in which the students are like depositories and the teacher is the depositor. Instead of communicating, the teacher makes deposits which the students patiently receive, memorize and repeat. In the last analysis, it is men [sic] themselves who are filed away through lack of creativity, transformation and knowledge in this (at best) misguided system. For apart from inquiry, men [sic] cannot be truly human. (p. 58)

While the drawbacks of the traditional lecture approach have existed since its inception, advances in technology and the advent of the information age, as mentioned earlier, make its exclusive use even more dubious. Brown \& Race (2002) refer to the traditional lecture /textbook method as the transmit and receive model of instruction. They pointed out that the transmit and receive model is clearly out of date, not only because the receivers were rarely tuned in, but also because in the twenty-first century students have only to connect to the world-wide web to be in touch with unlimited information. This phenomenon, unlike any other in the history of teaching, has shifted the role of the teacher from information provider to facilitator of learning.

Similarly, Fink (2003) observed that there were two widespread problems in education: most college instructors emphasize only lower - level thinking skills that emphasize understanding and remembering instead of the higher-level skills of application, analysis, synthesis, and evaluation and most rely on lecture as the primary instructional method. Out of these concerns Fink (2003) developed a "taxonomy of significant learning" that offers teachers a guide to creating learning experiences that engage students, promote high energy instead of boredom and results in lasting and self -directed learning.

In contrast to the traditional lecture method, active learning engages students in the learning process through discussion and small group work characterized by cooperative learning and collaborative learning techniques and as such positions the teacher in a facilitator role. Hunt, Haidet, Coverdale, and Richards (2003) examined student performance in cooperative learning situations, and found positive learning outcomes when compared to traditional lecture-based methods. Empirical research has shown that even in the most interesting lecture, attention levels naturally tend to drop (often dramatically) after the first 20 minutes of the presentation (Newble \& Cannon, 1995).

\section{RESISTANCE TO ACTIVE LEARNING IN HIGHER EDUCATION}

While the concept of active learning is not new and research has pointed to its effectiveness, it is an instructional approach reluctantly employed by college instructors. As Dodge (2011) observed:

Active learning isn't a new idea. It goes back at least as far as Socrates and was a major emphasis among progressive educators like John Dewey. And yet, if you peer into many classrooms, we seem to have forgotten that learning is naturally an active process. It involves putting our students in situations which compel them to read, speak, listen, think deeply, and write. While well delivered lectures are valuable and are not uncommon, sometimes the thinking required while attending a lecture is low level comprehension that goes from the ear to the writing hand and leaves the mind untouched. Active learning puts the responsibility of organizing what is to be learned in the hands of the learners themselves, and ideally lends itself to a more diverse range of learning styles. (p.1)

While interest in using active learning approaches in the college classroom is increasing there is still skepticism and a reluctance to give up the traditional lecture. As Paulson and Faust put it: 
The past decade has seen an explosion of interest among college faculty in the teaching methods variously grouped under the terms 'active learning' and 'cooperative learning'. However, even with this interest, there remains much misunderstanding of and mistrust of the pedagogical "movement" behind the words. The majority of all college faculty still teach their classes in the traditional lecture mode. $(2010$, p.1)

One factor contributing to this reluctance may be the fact that until recently there seemed to be no common definition of 'active learning'. In fact as Revell and Wainwright (2009) observed, not too long ago all learning was presumed to be active, and thus students were considered to be actively involved while listening to formal lectures in the classroom.

And as Bonwell and Eison (1991) observed:

educators' use of the term active learning has relied more on intuitive understanding than a common definition. Consequently, many faculty assert that all learning is inherently active and that students are therefore actively involved while listening to formal presentations in the classroom. (p.1)

But according to Rotenberg:

The least active form of learning is listening to the recitation of facts and then memorizing them for regurgitation on a quiz. This is not what effective lecturers do when they perform. Yet it passes for adequate teaching in large classes despite years of evidence that it puts more obstacles in the path of learning than it removes. $(2005, p .28)$

Paulson and Faust (2010) also contended that instructors tend to engage in "either or thinking" when it comes to lecture versus active learning. This thinking, according to Paulson and Faust, originates "in the idea that techniques of active and cooperative learning are genuine alternatives to, rather than enhancements of, professors' lectures" (p.1). In point of fact, they do not advocate the complete abandonment of lecturing but rather advocate the use of active learning techniques to enhance the effectiveness of the lecture. As Paulson and Faust put it:

The lecture is a very efficient way to present information but use of the lecture as the only mode of instruction presents problems for both the instructor and the students. There is a large amount of research attesting to the benefits of active learning. (2010, p.1)

\section{ACTIVE LEARNING AND LECTURE}

According to Jenkins and Pepper (1988) the prevailing wisdom amongst researchers is that students do not retain much in formal lectures unless they are alternated with activities that help increase comprehension. They conclude that making lectures as interactive as possible is critical to achieving higher levels of attention and retention in lecture based classrooms. In addition, research on group-oriented discussion methods has shown that cooperative learning and student-led discussion strategies not only produce favorable learning outcomes, but also foster greater participation, self confidence and leadership in students (Perkins \& Saris, 2001; Yoder \& Hochevar, 2005).

Thankfully, as Paulsen and Faust indicated, research also suggests there are strategies for incorporating active learning techniques into even large lecture courses. These active learning strategies can include asking for student comments, having the students break into small discussion groups, role-playing, and having students reflect in writing their reactions to class discussions (Angelo and Cross 1993; Carbone 1998; Frederick 1987; McKeachie 2002).

Effective management of large classes has become a popular topic among faculty in higher education. In fact, Carbone (1998) Stanley \& Porter (2002) Barkley, Cross and Major (2005) and Carpenter (2006) have produced books focused on the large class environment, offering strategies for student engagement and active learning.

Recent research by Huerta (2007) addressed the concern that many college lecturers have that using active learning techniques in large lecture setting will take too much time and diminish student mastery of content. His finding suggested that those concerns are not supported by the evidence. According to Huerta, 
At best, active learning has a positive impact on student learning as evidenced by the results of the exam grades and the pre-and post subject exams. At worst, active learning performs as well as non-active learning sections, indicating that active learning does not take time away from teaching. In addition, student attitudes were clearly more positive in the active learning sections. In summary, active learning does not lead to less learning and students are more likely to have positive attitudes. $(2007$, p. 246)

Interestingly, Revell and Wainwright (2009) made the case that lecturing combined with active learning techniques can be a powerful instructional strategy in the college classroom The results of their study suggested that staff and students consistently identified three key components to effective lectures: a high degree of student participation and interaction; a clear structure which enabled students to identify key points and make integrative links with other areas of the course, the passion and enthusiasm of the lecturer and the degree to which she/he can bring a subject to life. With regard to actively involving students in their own learning, Revell and Wainwright concluded that:

A good lecture was felt to include regular breaks for discussion and group activities, such as buzz groups, brainstorming, debates, role playing, plenary sessions, problem solving, presentation work-anything that got students involved and thinking for themselves. Students also liked to be given encouraging feedback on their thoughts and reflections, which in turn helped to stimulate their desire to learn more and communicate their ideas more effectively. Breaking the lecture up with activities was also considered a good way of avoiding the decline in attention levels that tends to develop as the lecture proceeds. (2009, p. 214)

In conclusion research and scholarly opinion suggest that active learning strategies are an effective way to engage students in their own learning as well as in higher-order thinking skills especially when compared to lectureonly approaches.

In this light the purpose of this study was to compare course evaluation responses of students enrolled in a graduate level human growth and development course taught with a traditional lecture/ textbook approach to the course evaluation responses of students enrolled in subsequent sessions of the same graduate level human growth and development course taught with an active learning approach.

\section{DESCRIPTION OF THE RESEARCH CONTEXT}

The study compared the student course evaluation quantitative and qualitative responses of three sections of a graduate level human growth and development course taught using traditional a lecture/textbook approach with the responses of two sections of the same course taught using active learning techniques. The three traditional sections were taught during the summers of 2007, 2008 and 2009 and the two active learning sections were taught during the summer of 2010. The graduate students enrolled in this course were pursuing a master's degree in either curriculum and instruction or educational administration. For most students it was the last course in a sequence of courses leading to their master's degree. The typical class consisted of from 15-28 students. All the classes in this study were taught in traditional 900 square foot classrooms equipped with movable tables and chairs, audio - video equipment, and internet access. The class sessions were approximately 3 hours in length.

Quantitative and qualitative data was collected at the conclusion of each section using the standard school student course evaluation form. All data was collected anonymously. Quantitative data was collected using a 5 point likert scale where $1=$ very poor and $5=$ very good. Written responses to open - ended was also collected and transcribed by a department secretary without any identifying data.

The first three sections of this course were taught in a traditional lecture format using a human growth and development survey textbook from a well known publisher. Students were assigned to read the material before each class. The instructor reviewed the material using power point presentations provided by the publisher. Whole group discussions were held periodically throughout the class session. The course concluded with each student giving a presentation on a human growth and development topic of their choice. 
For the purpose of this study the composite scores from the student course evaluations were used for comparison purposes. Quantitative data was analyzed using a standard $\mathrm{t}$ - test comparing the composite scores of the traditional lecture/ textbook classes to the composite scores of the active learning classes. Qualitative data consisted of the students' responses to open ended questions on the student course evaluation form regarding students' perceptions of course strengths and weaknesses as well as suggestions for improvements and general comments.

\section{TRADITIONAL LECTURE/TEXTBOOK APPROACH FINDINGS}

The average composite student evaluation score for the three lecture/ textbook based human growth and development courses was 4.28 while the average composite score for all department faculty teaching the same course was 4.51 . A total of 25 comments were generated by the students and $56 \%$ of the student comments referred to weaknesses or improvements needed while $44 \%$ of the comments referred to strengths.

An analysis of the student comments revealed four basic themes: thought provoking lectures, informative student presentations, repetition of undergraduate class, and modify the instructional method and materials. Student comments reflective of these themes are highlighted below.

\section{Thought provoking lecture}

A very thought provoking class.

The instructor shared many interesting and insightful bits of information.

Its content is interesting and can apply to the classroom.

\section{Informative student presentations}

The final project presentations are very informative and enlightening

\section{Repeat of undergraduate course}

This particular topic is a requirement at the undergrad level.

Seemed to be a repeat of a class that all educators have had in undergraduate course.

\section{Modify instructional methods and materials}

The power point lectures were deadly and the textbook was boring.

There is a lot of reading.

Modify the content.

More activities to help solidify the information.

The use of activities in addition to or in place of slides.

Could easily be done on - line.

\section{Using Student Evaluation As An Indicator of Student Learning}

Some researchers may question the use of student evaluations in measuring teacher effectiveness instead of more direct measures of student learning but as Theall and Franklin (2001) pointed out "While opinions on these matters are not direct measures of the performance of the teacher, they are legitimate indicators of student satisfaction, and there is a substantial research base linking this satisfaction to effective teaching" (p.49). According to Sajjad (2011) A meta-analysis of 41 research studies provides the strongest evidence for the validity of student ratings since these studies investigated the relationship between student ratings and student learning. Based on these findings Sajjad (2011) concluded that "There are consistently high correlations between students' ratings of the 'amount learned' in the course and their overall ratings of the teacher and the course" (p.1). And according to Murray (1994) research on student evaluation of teaching generally concludes that student ratings tend to be reliable, valid, relatively unbiased and useful. Finally, Braskamp (2000) suggested that instructors use feedback from student evaluations to formatively develop and improve their teaching effectiveness. 


\section{Subsequent Course Modifications}

Following Braskamp's suggestion, after examining student course evaluation data, it was clear that modifications needed to be made to the course particularly with regard to instructional methodology and instructional materials. As a result the instructional approach was changed from a traditional lecture/ textbook approach to one utilizing a mix of brief lectures (usually less than 15 minutes), active learning strategies and content from best- selling books.

These modifications were evident on the first day of class. During the first class session students were presented with an overview of several major theories of human development culminating with a summary of Bronfenbrenner's Ecological Systems Theory (1979). The Ecological Systems Theory was used throughout the course as a "unified" theory of human development that served as a frame of reference for discussing the theoretical underpinnings of human growth and development.

The learner expectations were shared with the students. These expectations included (a) writing a one page written response to the question "What was the most important thing you learned today and how will you apply it to your personal and/or professional life?" after each class session (b) writing a ten page paper on a human growth and development topic of their choice, (c) facilitating a class session with a partner using active learning techniques (d) using a class participation rubric to evaluate their own class participation.

During the first class session students were exposed to the concept of active learning and a sampling of specific active learning techniques they could use in facilitating the session for which they would be responsible. They were encouraged to use other techniques they might be familiar with or had used themselves. Students were also encouraged to use any of the technology available in the classroom or any they wanted to bring in to facilitate their session. Students were asked to turn on their laptops and smart phones and use them to research the topics being discussed. These active learning techniques shared during the first session included:

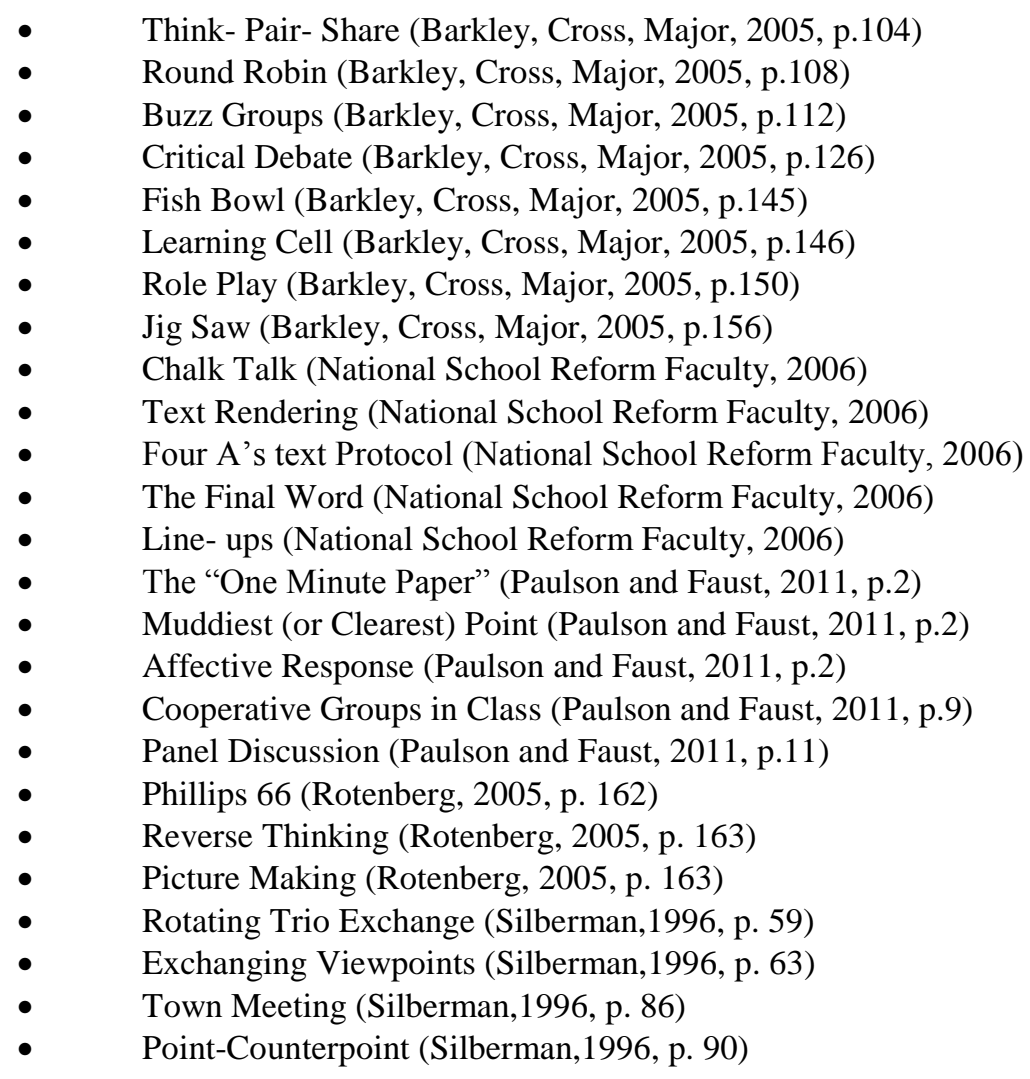


- Information Search (Silberman,1996, p. 100)

- $\quad$ Peer Lessons (Silberman,1996, p. 114)

- In the News (Silberman,1996, p. 118)

Students were asked to contribute any other active learning techniques they used in their classes.

Finally, an overview of the books that would be used in the class was provided. Based on the student feedback from the traditional lecture/textbook classes, the survey textbook was replaced with three best-selling books that focused on different aspects of human development:

Bronson, P. and Merryman, A. (2009) Nurture Shock: New Thinking About Children. New York: Hachette Book Group ISBN: 978-0446559416

Gladwell, M. (2008) Outliers: The Story of Success. New York: Hachette Book Group ISBN: 9780316017923

Medina, J. (2008). Brain Rules: 12 Principles for Surviving and Thriving at Home, Work, and School. Seattle, WA: Pear Press ISBN: 978-0979777745

After the overview the students were told that he instructor would be responsible for facilitating the teaching and learning of the first book using a combination of short lecture and some of the cooperative learning techniques listed above and that the remaining two books would be the responsibility of pairs of classmates using short lecture and active learning techniques. The students spent the last portion of the first class choosing teaching partners and the topics they would teach.

During the term students were encouraged to compare the findings and claims in these books with the tenets of Bronfenbrenner's Ecological Theory and with research they could find on-line using EBSCO Academic Search Complete. Additionally, students were encouraged to supplement their classroom presentations with multimedia and University on-line research resources. As questions arose during small group discussions students were also encouraged to consult, in real-time, on-line resources through the use of their lap tops and smart phones and share their findings with the class.

\section{ACTIVE LEARNING APPROACH FINDINGS}

At the conclusion of the active learning classes students were asked to complete the standard department course evaluation form. The average composite student evaluation score for the two active learning based human growth and development sections was 4.85 while the average composite score for all faculty teaching the same course was 4.51. T-test results indicate that students taking the active learning based human growth and development course rated it higher $(\overline{\mathrm{x}}=4.85, S D=.153)$ than did those taking the traditional lecture/textbook human growth and development $(\overline{\mathrm{x}}=4.28, S D=.0832), t(3)=-7.78, p=.0004)$.

The quantity, (which was significantly greater than the traditional lecture classes) and quality of the comments bore this out as well.

A total of 71 comments were generated by the students and $92 \%$ of the comments pointed to a strength of the course. An analysis of the student comments revealed five basic themes: (a) a focus on application of content (b) engaging, active, technology -friendly instructional methods (c) meaningful learning (d) engaging and interesting instructional materials (e) opportunities to cooperate and collaborate. Student comments reflecting these themes are highlighted below.

\section{A Focus On Application Of Content}

This course was one of the rare courses where not only did I learn things; I learned things that I can apply in my future.

I learned more practical application to my professional life in this class than any other class I have taken. 
Writing a personal reaction paper after each class helped me to remember what I read and apply it to my life."

I am excited to go back to my classroom and implement what I have learned in this class.

\section{Instructional Methods}

This class is taught as we should teach as teachers.

Great methods, highly interactive. I would recommend this format to others.

Instruction was facilitated through group discussions which led to a greater deal of learning.

Using technology as a learning tool in the classroom was a plus.

\section{Meaningful Learning}

This class is by far the most meaningful class that I took in my degree program. The structure of the classroom allowed me the opportunity to really grow and understand my job as an educator more clearly.

I learned lots more in this class than the typical college format.

I actually enjoyed learning in this class - unique for the grad level.

Learned more than I expected.

This course was one of the rare courses where not only did I learn things that I can apply in my future, I learned things that I will remember and use.

I loved how we had very practical discussions about real life experiences. The class kept my attention while learning at the same time.

Keep creating classes like this! Very refreshing especially after two years of grad work.

\section{Engaging And Interesting Instructional Materials}

This was an excellent course structured in a very practical \& engaging manner.

The course was of high interest in that we used best-selling books as the text.

Really enjoyed the set up of this class, the text related strongly to hot topics in education.

I loved the creative aspects of this course. Reading the three books on recent research on education and the way the brain works was very insightful for my personal and professional life. "This was the first graduate course that held my attention and sparked my interest.

This is the best/most relevant/interesting graduate class I have taken.

More professors should use this book study type of approach to teaching. This has been one of the most interesting and educational graduate classes I have taken.

Great format, book study method was great. Awesome class discussions \& material; applicability was awesome. 
This course stepped out of the norm of kill and drill and allowed us to read some well known books and apply them to our real world situations and education. The books we read are actually books that I will keep and refer back to/reread as they are not your usual bore you to death textbooks.

The books chosen were books I would recommend to other teachers to use as a book study and will refer to as they contained practical knowledge that any teacher or administrator can use. The books used for this course provide much more knowledge than a textbook.

Loved that we did not use the "standard" text. Learned more about human growth \& development in this format.

I liked how the course material was integrated into real life text and reading versus just textbooks. I felt more connection to the material this way. It helped me to see how I can apply information personally and professionally.

\section{Opportunities For Cooperation And Collaboration}

Relaxed to the point of everybody seemed comfortable to give their opinion; students wanted to read the given assignments out of interest rather than necessity.

For graduate level, this format - groups, peer presentations, discussion, etc. - is far more effective and useful.

Atmosphere -instructor made class fun, interesting, and useful. Students felt at ease \& willing to participate.

I liked that we were all learning from one another through open discussion. It was very unthreatening and I enjoyed attending each session.

Very interactive and participatory.

Great methods, highly interactive. I would recommend this format to others.

Another strength of this class is the way it was taught with us being involved in the discourse and a major part of the learning.

I liked the self reflection after each class, making this interactive on Blackboard chat might promote collaboration and the spread of best practices.

\section{SUMMARY OF FINDINGS}

An analysis of quantitative data revealed that students rated the active learning sections significantly higher $(\overline{\mathrm{x}}=4.85)$ than the traditional lecture sections $(\overline{\mathrm{x}}=4.28)$. The mean score for the active learning sections was also higher than the overall department mean for the human growth and development course of 4.51. An analysis of qualitative data indicated that students rated active learning instruction more favorably that traditional lecture instruction. Four overall themes were evident from the open ended responses of students with regard to the traditional lecture classes. Those themes were: (a) thought provoking lectures (b) repetition of undergraduate course work (c) informative final project presentations by students and (d) modify content and instructional strategies and materials. Students seemed to think that the instructor added interesting insights into textbook based lecture material, that the content was repetitive of undergraduate course work and while they liked the final project presentations, the content as well as the instructional strategies and materials should be modified. Five overall themes were evident from the open ended responses of students with regard to the active learning classes. Those themes were: (a) a focus on applying content (b) active, engaging, and technology friendly instruction (c) meaningful learning (d) interesting instructional materials and (e) opportunities to cooperate and collaborate. Students expressed an appreciation for a class that focused on the application of content; that was active, engaging and encouraged the use of technology as a learning tool; that resulted in a meaningful learning experience; that used interesting instructional materials and that offered them an opportunity to cooperate and collaborate. 
Table 1. Means, Standard Deviations, And T-Test Results Student Course Evaluation Ratings

\begin{tabular}{|l|c|c|c|c|c|c|}
\hline \multicolumn{1}{|c|}{ Instructional Approach } & $\mathbf{n}$ & $\overline{\mathbf{x}}$ & $\mathbf{S D}$ & $\mathbf{d f}$ & $\mathbf{t}$ & $\mathbf{p}$ \\
\hline Traditional Lecture & 55 & 4.28 & .083 & 3 & -7.78 & .0004 \\
\hline Active Learning & 30 & 4.85 & .153 & 3 & & \\
\hline
\end{tabular}

Note. Rating scale $1=$ Very Poor, $5=$ Very Good

Taken together the quantitative and qualitative data suggest that not only did students prefer an active learning approach to instruction they also believed they learned more with such an approach.

\section{DISCUSSION AND IMPLICATIONS}

There is much for college instructors to consider from this study; primarily that a combination of short lecture and active learning techniques can create a classroom climate very conducive to meaningful learning. This appears true for a number of reasons supported by this study.

First, it is clear that students in this study were more positive about their experiences with the active learning classroom than they were about the traditional lecture based classroom. It also appears clear that students believed they learned more and were able to apply what they learned to a greater degree in the active learning classroom than the traditional lecture based classroom and students seemed to enjoy learning in the active learning classroom as compared the lecture based classroom.

Second, the results of this study suggest that the active learning classroom can serve as a model for those students, as was the case in these classes, who teach. Even for those students who are not teachers an active learning approach with its emphasis on cooperation and collaboration serves as an excellent model for anyone involved in an organization that values team work and problem solving.

Third, an active learning approach, coupled with a book study appears to model many of the aspects of a professional learning community that many educators are a part of in the school districts they serve. The emphasis in professional learning communities is professionals cooperating and collaborating to create a school environment conducive to high levels of student achievement. It would appear that an the active learning classroom with its focus on cooperation, collaboration and engaged learning serves as a good model for a professional learning community.

Fourth with increasing demand for individuals in the work force who can apply higher- order thinking to challenges in the work place the active learning classroom seems an ideal place to begin to foster the development and application of those skills within the context of working with peers to accomplish a goal, solve a problem, or reach a consensus. Such skills will become increasingly in demand in the $21^{\text {st }}$ century.

Fifth, the active learning classroom also appeared to facilitate and embrace the use of technology, especially the use of devices that enabled students to connect with the world - wide web. Rather than interfering or distracting students from a lecture, lap tops and smart phones connected to the internet actually enhanced the learning experience for both the students and the instructor. Interestingly, while students in the lecture based classroom thought the lecture based content would be suitable for an on-line class, students in the active learning class never mentioned converting this class to an on-line course even though they did mention making an on-line blog a supplemental enhancement of the class. No doubt there may be something about a face- to-face active learning experience that is difficult to replicate on -line.

And finally, from the perspective of the instructor, the active learning class, while requiring as much planning as the lecture - based class, was much more satisfying to teach. To the casual observer peeking into the classroom, it was difficult to distinguish between instructor and student, as those roles were continually interchanged. The excitement of the students and the instructor as they engaged each other in learning was contagious so much so that both the instructor and the students could not wait for the next class to begin. One student summed it up the learning experience for both instructor and students... "I actually enjoyed learning in this class!" 


\section{CONCLUSION}

It is clear from this study and others like it that active learning and lecture are not mutually exclusive pedagogies; in fact they actually complement each other very well. While listening is certainly important first step in gaining knowledge ultimately for students to truly learn they need opportunities to actually do something with the content being presented other than just listen to it. Students need to be actively engaged in integrating and reconciling new knowledge with existing knowledge so that they come to own it in a meaningful, insightful way. Active learning techniques can help student come to own their learning in ways that a strict lecture approach cannot especially when it has been shown that active learning engages student in higher -order critical thinking skills; skills that are in many ways the sine quibus non of the information age. For as Freire (1975) put it " ultimately, learning is not just about knowledge acquisition - it is about expanding consciousness: Knowledge emerges only through invention and reinvention, through the restless, impatient, continuing, hopeful inquiry men pursue in the world" (p.58). Active learning strategies can help students and instructors in their shared pursuit of knowledge.

\section{AUTHOR INFORMATION}

Paul Johnson is an assistant professor of Leadership and Policy Studies in the College of Education and Human Development at Bowling Green State University where he teaches human growth and development, school community relations, school finance and public policy. He is a former psychologist, superintendent, and current board of education member with the Bucyrus City School District in Ohio.

\section{REFERENCES}

1. Angelo, T. A., \& Cross, K. P. (1993). Classroom assessment techniques (2nd Ed) San Francisco, CA: Jossey-Bass Publishers.

2. $\quad$ Astin, A. (1993). What matters in college? San Francisco: Jossey-Bass.

3. Barak, M., Ben-Chaim, D., \& Zoller, U. (2007). Purposely teaching for the promotion of higher-order thinking skills: A case of critical thinking. Res Sci Educ 37, 353-369.

4. Barkley, E.F., Cross, K.P., \& Major, C.H. (2005). Collaborative Learning Techniques: A handbook for College Faculty. San Francisco, CA: Jossey - Bass.

5. Bonwell, C. C., \& Eison, J. A., (1991) Active learning: Creating excitement in the classroom. ASHE-ERIC Higher Education Report No. 1. Washington, DC: George Washington University, School of Education and Human Development.

6. Braskamp, L. A. (2000). Toward a more holistic approach to assessing faculty as teachers. In K. E. Ryan (Ed.), Evaluating teaching in higher education: A vision for the future. New directions for teaching and learning (pp.109-123). San Francisco, Ca: Jossey-Bass.

7. Bronfenbrenner, U. (1979). The ecology of human development: Experiments by nature and design. Cambridge, MA: Harvard University Press.

8. Brown, S., \& Race, P. (2002). Lecturing: A practical guide. London: Kogan Page.

9. Carpenter, J.M. (2006). Effective teaching methods for large classes. Journal of Family \& Consumer Sciences Education, 24(2), 13-23.

10. Chickering, A. W., \& Gamson, Z.F. (1987). Seven principles for good practice in undergraduate education. The Wingspread Journal, 9(2), 3-7. See also AAHE Bulletin, March 1987.

11. Carbone, E. (1998). Teaching large classes: Tools and strategies. Thousand Oaks, CA: Sage.

12. De Caprariis, P., Barman, C., \& Magee, P. (2001). Monitoring the benefits of active learning exercises in introductory survey courses in science: An attempt to improve the education of prospective public school teachers. The Journal of Scholarship of Teaching and Learning, 1(2), 1-11.

13. Dodge, B., (1996). Active Learning on the Web. Retrieved from http://edweb.sdsu.edu/people/ bdodge/active/ActiveLearningk-12.html

14. Exley, K., \& Dennick, R. (2004). Giving a lecture: From presenting to teaching. London: Routledge Falmer.

15. Fink, L.D. (2003). Creating significant learning experiences: An integrated approach to designing college courses. SanFrancisco: Josey-Bass. 
16. Frederick, P. J. (1987). Student involvement: Active learning in large classes. New Directions in Teaching and Learning, 1987 (32), 45-56.

17. Freire, P. (1975). Education for critical consciousness. New York: Continuum.

18. Huerta, J.C. (2007). Getting active in the large lecture. Journal of Political Science Education, 3, $237-249$.

19. Hunt, D., Haidet, P., Coverdale, J., \& Richards, B. (2003). The effect of using team learning in an evidence-based medicine course for medical students. Teaching and Learning in Medicine, 15(2), 131-139.

20. Jenkins, A., \& Pepper, D. (1988). Enhancing students' employability and self-expression: how to teach oral and groupwork skills in geography. Journal of Geography in Higher Education, 12(1), 67-83.

21. McKeachie, W.J., Pintrich, P.R., Lin, Y., \& Smith, D.A. (1986). Teaching and learning in the college classroom: A review of research literature. Ann Arbor: University of Michigan, National Center for Research to Improve Postsecondary teaching and learning.

22. McKeachie, W.J. (2002). McKeachie's teaching tips: Strategies, research, and theory for college and university teachers (11th Ed.) Boston: Houghton Mifflin.

23. Meyers, C., \& Thomas B. J. (2003) Promoting active learning: Strategies for the college classroom. San Francisco:, CA: Jossey-Bass Publishers.

24. Murray, H. G. (1994). Can teaching be improved? Canada: Brock University.

25. Newble, D., \& Cannon, R. (1995). A handbook for teachers in universities \& colleges: A guide to improving teaching methods. (3rd Ed.) London: Kogan Page.

26. Oliver, H. \& Utermohlen, R. (1995). An innovative teaching strategy: Using critical thinking to give students a guide to the future. (Eric Document Reproduction Services No. 389 702).

27. Paulson, P.R. \& Faust, J.L. (2011). Active learning for the college classroom. Retrieved from http://www.calstatela.edu/dept/chem/chem2/Active/

28. Perkins, D., \& Saris, N. (2001). A jigsaw classroom technique for undergraduate statistics courses. Teaching of Psychology, 28(2), 111-113.

29. Prince, M. (2004) Does active learning work? A review of the research. Journal of Engineering Education.93 (3), 223-232.

30. National School Reform Faculty. (2011). Protocols. Retrieved from http://www. nsrfharmony.org/ protocol/protocols.html

31. Ramsden, P. (1996). Learning to teach in higher education. New York: Routledge.

32. Raviv, A. (2009). Academic Skills: The Key to Meaningful Learning in Higher Education-An Action Research. International Journal of Learning, 16(8), 377-391.

33. Revell, A., \& Wainwright, E. (2009). What makes lectures "unmissable"? Insights into teaching excellence and active teaching. Journal of Geography in Higher Education, 33(2), 209-223.

34. Rotenberg, R. (2005). The art and craft of college teaching: A guide for new professors \& graduate students. Chicago, Il: Active Learning Books.

35. Sajjad, S. S. (2011). Effective teaching methods at higher education level. Retrieved from http://www.wfate.org/papers/Research_paper_Teaching_methods.pdf

36. Silberman, M. (1996). Active learning: 101 strategies to teach any subject. Boston, MA: Allyn and Bacon.

37. Stanley, C., \& Porter, E. (Eds.). (2002). Engaging large classes: Strategies and techniques for college faculty. Bolton, MA: Anker Publishing Company.

38. Ten Dam, G. \& Volman, M., (2004). Critical thinking as a citizenship competence: Teaching strategies. Learning and Instruction (14) 359-379.

39. Theall, M. \& Franklin, J. (2001). "Looking for bias in all the wrong places: A search of truth or witch hunt in student ratings of instruction?" New Directions for Institutional Research 109: 45-56.

40. Yoder, J. \& Hochevar, C. (2005). Encouraging active learning can improve students' performance on examinations. Teaching of Psychology, 32(2), 91-95. 